\title{
FIRST-LINE TREATMENT OF OVARIAN CANCER FIGO STAGES IIIB-IV: FOCUS ON THERAPY WITH BEVACIZUMAB - OUR EXPERIENCE
}

\author{
KRISTINA KATIĆ, VIŠNJA MATKOVIĆ, JOŠKO LEŠIN, GORAN VUJIĆ, \\ PAVAO PLANINIĆ and ANTE ĆORUŠIĆ
}

Department of Gynaecology and Obstetrics, University Hospital Centre Zagreb, Zagreb, Croatia

\begin{abstract}
Summary
Epithelial ovarian cancer is the seventh most common cancer among women and the leading cause of gynecological cancer related deaths in Croatia. Approximately 70\% of patients are diagnosed at an advanced stage of the disease (FIGO III and IV). The usual approach to treatment involves complete surgical cytoreduction (R0), followed by combined platinumbased chemotherapy. Bevacizumab is recommended to add to paclitaxel/carboplatin chemotherapy in patients diagnosed at FIGO IIIB and IIIC stage with residual disease after surgery and all patients FIGO IV stage of disease, which can extend the time to progression of the disease in these patients.

In this retrospective study, we analyzed the medical data of 98 patients with newly diagnosed advanced FIGO IIIB-IV epithelial ovarian, fallopian tube, or primary peritoneal cancer treated at the Department of Gynecology and Obstetrics in the University Hospital Centre Zagreb in the period from January 2017 to December 2018. We have analyzed the following data: age, ECOG status, FIGO stage of disease, principle of surgery, pathohistological type of the tumor, number and type of adjuvant chemotherapy, application of bevacizumab, number of bevacizumab cycles, side effects related to bevacizumab therapy.
\end{abstract}

Data from 98 patients were obtained. The median age was 60 years. The most patients were ECOG status 0-1 (78 \%). According to the pathohistological findings, $89 \%$ of patients had serous carcinoma, $5 \%$ endometrioid carcinoma, 3\% mucinous carcinoma, $1 \%$ clear cell carcinoma, 1\% borderline tumors and 1\% poorly differentiated epithelial carcinoma. Most of the patients $(68.5 \%)$ were underwent to primary cytoreduction, $12 \%$ "interval debulking" operation, whereas biopsy was performed in only $19.5 \%$ patients. HIPEC during surgery had $6 \%$ of patients. Resection without residual disease was achieved in only $25.5 \%$ of patients underwent surgery, while in others were reported macroscopic residual disease after surgery. $87 \%$ of patients were treated with chemotherapy with paclitaxel and carboplatin in three weeks schedule. 38 patients received antiangiogenetic drug bevacizumab. After exclusion of patients with a poor general condition (ECOG 2-4) and patients with FIGO stage IIIB and IIIC without residual disease after surgery, the percentage of patients receiving bevacizumab was 56\% in 2017 and 75\% in 2018. The average number of received cycles was 13 (range 1-22), and 8 patients continued the therapy in May 2019. Sixty-eight percent of the patients which received bevacizumab did not have any side effects associated with the bevacizumab therapy. The most common side effects associated with the bevacizumab were hypertension, development of deep vein thrombosis, ileus and proteinuria.

In Croatia, since February 2017, we have the possibility of using bevacizumab for the treatment of newly diagnosed ovarian cancer patients stage IV or incompletely resected patients stages III B and III C. Our results are in concordance with the literature data and show that we can safely add bevacizumab to the first line chemotherapy of advanced ovarian cancer.

KEYWORDS: ovarian cancer, advanced stage of the disease, therapy, bevacizumab 


\section{PRVOLINIJSKO LIJEČENJE RAKA JAJNIKA FIGO STADIJA IIIB-IV: NAGLASAK NA LIJEČENJU BEVACIZUMABOM - NAŠE ISKUSTVO}

\section{Sažetak}

Epitelni rak jajnika je sedmi najčešći maligni tumor u ženskoj populaciji i najčešći uzrok smrti od malignih ginekoloških tumora u Hrvatskoj. U vrijeme dijagnoze, oko 70\% bolesnica nalazi se u uznapredovalom stadiju bolesti (stadiji FIGO III i IV). Uobičajeni pristup liječenju uključuje pokušaj kompletne kirurške citoredukcije (R0), nakon koje slijedi kombinirana kemoterapija na bazi platine. Kod bolesnica stadija bolesti FIGO IIIB i IIIC kod kojih postoji ostatna bolest nakon operativnog zahvata ili pak kod stadija FIGO IV, preporučuje se kemoterapiji dodati inhibitor angiogeneze (bevacizumab), kojim se može produžiti vrijeme do progresije bolesti u tih bolesnica.

Ovom retrospektivnom analizom obuhvatili smo medicinske podatke 98 bolesnica s novodijagnosticiranim uznapredovalim (FIGO IIIB-IV) epitelnim rakom jajnika, jajovoda ili primarnog peritonealnog raka liječenih u Klinici za ginekologiju i porodništvo, Kliničkog bolničkog centra Zagreb u razdoblju od 01.01.2017. do 31.12.2018. Ispitivali smo slijedeće parametre: dob, ECOG status, stadij bolesti, princip kirurškog liječenja, patohistološki tip tumora, tip i broj kemoterapijskih ciklusa, aplikacija bevacizumaba, broj ciklusa bevacizumaba, te nuspojave povezane sa terapijom bevacizumabom.

Obrađeni su podaci 98 bolesnica. Prosječna dob bolesnica bila je 60 godina. Većina bolesnica bila je ECOG status 0-1 (78 \%). Prema patohistološkom nalazu, serozni karcinom utvrđen je u 89\% bolesnica, u 5\% endometrioidni, 3\% mucinozni, a po $1 \%$ su bili zastupljeni klarocelularni, bordeline tumori i slabo diferencirani epitelni karcinom. Većina bolesnica (68.5\%) je podvrgnuta primarnoj citoredukciji, 12\% "interval debulking" operaciji, dok je u 19.5\% učinjena samo biopsija tumora. U $6 \%$ bolesnica je tijekom operacije proveden HIPEC. Resekcija bez rezidualne bolesti postignuta je u $25.5 \%$ bolesnica podvrgnutih operativnom zahvatu, dok je u drugih bolesnica zabilježena ostatna makroskopska bolest nakon operativnog zahvata. Trotjednom kemoterapijom paklitaksel/karboplatin liječeno je $87 \%$ bolesnica. Terapiju inhibitorom angiogeneze (bevacizumab) primilo je 38 bolesnica. Kada isključimo bolesnice lošeg općeg stanja (ECOG 2-4) te bolesnice bez ostatne makroskopske bolesti nakon operativnog zahvata stadija FIGO IIIB i IIIC, postotak bolesnica koje su primile bevacizumab bio je $56 \%$ u 2017. godini i 75\% u 2018.g. Prosječni broj primljenih ciklusa je 13 (raspon 1-22), a 8 bolesnica nastavilo je navedenu terapiju i u svibnju 2019. 68\% bolesnica koje su liječene bevacizumabom nisu imale nikakvih nuspojava povezanih sa navedenom terapijom. Najčešće zabilježene nuspojave povezane s terapijom bevacizumabom bile su hipertenzija, razvoj duboke venske tromboze, ileus i proteinurija.

U Hrvatskoj, od veljače 2017. godine imamo mogućnost primjene bevacizumaba u liječenju bolesnica s novodijagnosticiranim rakom jajnika stadija IV ili stadija IIIB i IIIC kod kojih postoji ostatna bolest nakon operativnog zahvata. Naši rezultati su u skladu s literaturnim podacima i pokazuju da sigurno možemo dodati bevacizumab prvolinijskom liječenju u bolesnica s uznapredovalim rakom jajnika.

KLJUČNE RIJEČI: rak jajnika, uznapredovali stadij bolesti, liječenje, bevacizumab

\section{INTRODUCTION}

Epithelial ovarian cancer is one of the leading causes of cancer related deaths in women worldwide. According to global estimates 295,414 new cases were detected in 2018, and 184,799 people were died from the disease (1). In Croatia, it is the seventh most common cancer among women and the leading cause of gynecological cancer death. The estimated number of new ovarian cancer cases in Croatia in 2016 was 425 with 301 deaths (2). Commonly, it is staged using the FIGO (International Federation of Gynecology and Obstetrics) staging system (3). More than $70 \%$ of affected women are diagnosed at an advanced stage of disease because early-stage disease is usually asymptomatic and symptoms of late stage of disease are nonspecific. The standard treatment of our patients is cytoreductive surgery followed by platinum based chemotherapy $(4,5)$. Complete resection of all macroscopic disease has been shown to be the most important prognostic factor in advanced ovarian cancer $(6,7)$. Standard chemotherapy consists of a combination of paclitaxel 175 $\mathrm{mg} / \mathrm{m}^{2}$ and carboplatin AUC 5-6, both administered intravenously every 3 weeks. In patients with a disseminated disease, one option is neoadjuvant chemotherapy with interval debulking surgery after three to four cycles of chemotherapy $(4,5,8)$.

Bevacizumab is a recombinant humanized anti-VEGF monoclonal antibody. It is used in the treatment of many cancers. Bevacizumab is the first targeted therapy approved by the European 
Medicines Agency (EMA) for the treatment of the advanced ovarian cancer, fallopian tube, or primary peritoneal cancer stage III or IV in combination with carboplatin and paclitaxel in the first line therapy. It is approved due to the results of two randomized controlled Phase III trials: GOG-0218 and ICON-7 study $(9,10)$. The both these studies demonstrated an improvement of progressionfree survival (PFS), especially in the high-risk ovarian cancer population. Based on these two studies, The Croatian Institute for Health Insurance also approved bevacizumab for high- risk ovarian, fallopian tube or primary peritoneal cancer: in patients with a FIGO stage IIIB-IIIC with residual disease after surgery and in all patients with FIGO stage IV. The recommended dose of bevacizumab in the first line therapy is $15 \mathrm{mg} / \mathrm{kg}$ every 3 weeks with carboplatin and paclitaxel for up to six cycles, followed by $15 \mathrm{mg} / \mathrm{kg}$ every 3 weeks as a single agent, for a total of up to 22 cycles.

\section{PATIENTS AND METHODS}

In this retrospective study, we have analyzed the medical data of 98 patients with newly diagnosed advanced FIGO IIIB-IV epithelial ovarian, fallopian tube, or primary peritoneal cancer treated at the Department of Gynecology and Obstetrics in the University Hospital Centre Zagreb in the period from January 2017 to December 2018. We have analyzed the data: age, ECOG status, stage of disease, principle of surgery (primary surgery or interval debulking surgery), pathohistological type of the tumor, number and type of adjuvant chemotherapy, application of bevacizum$\mathrm{ab}$, number of bevacizumab cycles, side effects related to bevacizumab application. Patients were followed up until May 2019. Quantitative variables were expressed as mean and median values. Qualitative variables are expressed as absolute and relative frequencies.

\section{RESULTS}

Ninety-eight patients with advanced ovarian cancer, fallopian tube or primary peritoneal cancer (with FIGO stage IIIB-IV) were treated in our institution during a period between January 2017 and December 2018. The median age was 60 years (range $34-85$ years). For $57 \%$ of the patients $(\mathrm{N}=56)$, the tumor occurred between seventh and ninth decades of life. The most patients were ECOG status $0-1(78 \%)$. We also treated $8 \%$ of patients with poor general condition $(E C O G \geq 3)$. All investigated patients were in advanced stage of disease, but the most patients $(61 \%)$ were FIGO stage IIIC and FIGO stage IVB (24\%). According to pathohistological findings, serous carcinoma was the most often tumor in our patients $(88.8 \%)$. The others patohistological types of tumor were: endometrioid $(5 \%)$, mucinous $(3 \%)$, clear cell $(1 \%)$, borderline tumors $(1 \%)$ and poorly differentiated epithelial carcinoma (1\%).

Table1.

CHARACTERISTICS OF PATIENTS

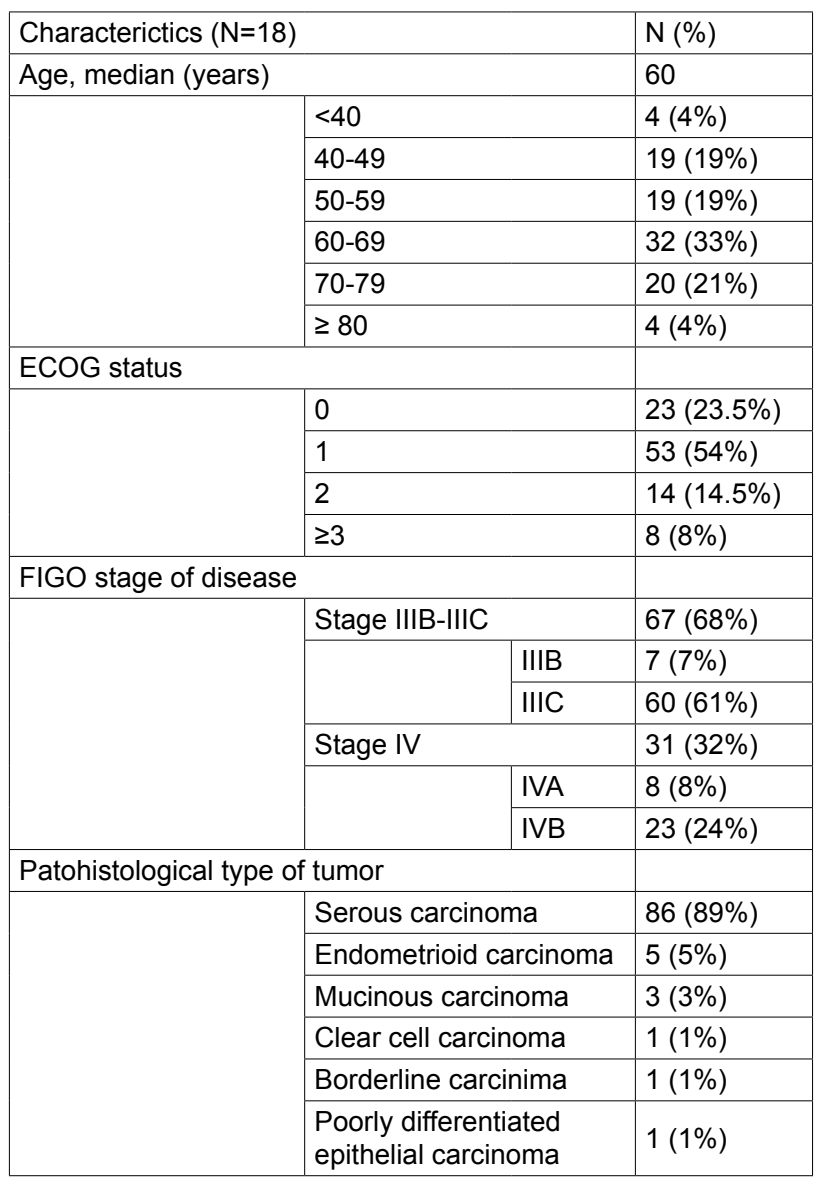

Most of the patients (68.5\%) had primary cytoreduction, $12 \%$ "interval debulking" operation, whereas biopsy was performed in only $19.5 \%$ patients. HIPEC during surgery had $6 \%$ of patients. Resection without residual disease was achieved in only $25.5 \%$ of patients underwent surgery, 
Table 2.

\section{PERFORMED SURGICAL PROCEDURES}

\begin{tabular}{|l|l|l|l|}
\hline Surgery & $\begin{array}{l}\text { Number of } \\
\text { patients } \\
\text { (percentage) }\end{array}$ & $\begin{array}{l}\text { Number of } \\
\text { patients without } \\
\text { residual } \\
\text { disease after } \\
\text { surgery } \\
\text { (percentage) }\end{array}$ & $\begin{array}{l}\text { Number of } \\
\text { patinets with } \\
\text { residaual } \\
\text { disease after } \\
\text { surgery } \\
\text { (percentage) }\end{array}$ \\
\hline $\begin{array}{l}\text { Primary } \\
\text { cytoreduction }\end{array}$ & $67(68 \%)$ & $22(22.5 \%)$ & $45(46 \%)$ \\
\hline $\begin{array}{l}\text { „Interval } \\
\text { debulking” } \\
\text { surgery }\end{array}$ & $12(12 \%)$ & $3(3 \%)$ & $9(9 \%)$ \\
\hline Biopsy & $19(20 \%)$ & $0(0 \%)$ & $19(19.5 \%)$ \\
\hline Sumary & $98(100 \%)$ & $25(25.5 \%)$ & $73(74.5 \%)$ \\
\hline
\end{tabular}

while in others were reported macroscopic residual disease after surgery (Table 2).

$87 \%$ of patients were treated with chemotherapy with paclitaxel (175 mg/m², $3 \mathrm{~h}$ intravenously) followed by carboplatin (AUC 5, Calvert formula) on a 3-weekly schedule, while the other $13 \%$ received chemotherapy with cyclophosphamide $\left(600 \mathrm{mg} / \mathrm{m}^{2}\right.$, intravenously) followed by carboplatin $\left(300 \mathrm{mg} / \mathrm{m}^{2}\right.$ or AUC 6, Calvert formula), on a 4-weekly schedule. Chemotherapy with cyclophosphamide and carboplatin was administered in patients with cardiovascular diseases in medical history, with poor general condition and according to personal wishes of the patients. The average number of administered chemotherapy cycles was 6 (range 1-10).

38 patients received antiangiogenetic drug bevacizumab. After exclusion of the patients with poor general condition (ECOG 2-4) and patients with stage FIGO IIIB and IIIC without residual disease after surgery, the percentage of patients receiving bevacizumab was 56\% in 2017 and 75\% in $2018.11 \%$ of patients treated with bevacizumab were older than 70 years. The average number of received cycles was 13 (range 1-22). Eight patients continued to receive bevacizumab therapy after May 2019. Eighteen percent of the patients $(N=7)$ received all planned 22 cycles of bevacizumab, and four of them are disease free till now. Three patients discontinued bevacizumab therapy because of the side effects, in one patient occured vesicovaginal fistula, one patient had symptoms of subileus and one patient was underwent to surgery because of ileus. Sixty-eight percent of the patients on bevacizumab therapy did not have any side effects associated with the therapy. The most common adverse events associated with bevacizumab therapy were hypertension $(7 \%)$, development of deep vein thrombosis $(7 \%)$, ileus $(5 \%)$ and proteinuria $(5 \%)$. Something less common adverse events observed in bevacizumab patients were vesicovaginal fistula $(3 \%)$, headache (3\%) and tachycardia (3\%) (Table 3).

Table 3.

ADVERSE EVENTS ASSOCIATED WITH BEVACIZUMAB THERAPY

\begin{tabular}{|l|l|}
\hline Adverse events & $\begin{array}{l}\text { Number of patients } \\
\text { (percentage) }\end{array}$ \\
\hline Hypertension & $3(8 \%)$ \\
\hline DVT & $3(8 \%)$ \\
\hline Ilues & $2(5 \%)$ \\
\hline Proteinuria & $2(5 \%)$ \\
\hline Vesicovaginal fistula & $1(3 \%)$ \\
\hline Headache & $1(3 \%)$ \\
\hline Tachycardia & $1(3 \%)$ \\
\hline
\end{tabular}

\section{DISCUSSION}

Ovarian cancer is predominantly a disease of postmenopausal women and the majority of patients are in the age of over 50 years. Most of the patients are diagnosed at an advanced stage of the disease. Primary cytoreduction followed by a three-weekly paclitaxel-carboplatin chemotherapy is currently considered as the standard of care for ovarian cancer (4.5). Optimal cytoreduction is defined as total macroscopic tumor clearance with no residual visible disease. This has been shown to be associated with a significantly increased OS and PFS $(7,11)$. In patients with wide and aggressive tumor dissemination, an alternative treatment strategy is neoadjuvant chemotherapy (NACT) followed by interval debulking surgery (8). In both cases, it is recommended that the primary surgery should be performed by a gynecologic oncologist, rather than by general gynecologist or by general surgeon $(12,13)$. The value of systematic pelvic and para-aortic lymphadenectomy in advanced disease is controversial. The prospectively randomized phase III LION trial investigated lymphadenectomy with no lymphadenectomy in patients $(\mathrm{N}=647)$ with newly diagnosed advanced ovarian cancer (FIGO stage IIB- 
IV) who had undergone macroscopically complete surgical resection and had visibly normal lymph nodes. This trial confirmed that patients with advanced ovarian cancer and clinically negative lymph nodes who underwent maximal macroscopic cytoreduction do not benefit from lymphadenectomy and it is associated with increased incidence of postoperative complications (14). Every operative report should comprise the following facts: the extent of the disease, whether a complete or incomplete resection is achieved and if incomplete resection is done, the site and the amount of residual disease.

Systemic antineoplastic therapy is indicated in all patients with advanced ovarian cancer. Firstline chemotherapy with carboplatin and paclitaxel became the standard chemotherapy combination more than 20 years ago (15). Despite a high initial response rate to the primary treatment, many patients have relapse of the disease and die at the end. To increase overall survival, some clinical trials have investigated intraperitoneal application of drugs or dose-dense regimens. GOG 172, the clinical trial phase III demonstrated a benefit in PFS and OS for a regimen that included intraperitoneal (IP) applicaton of cisplatin on day 2 and paclitaxel on day 8 and intravenous paclitaxel on day 1 compared with the standard regimen with paclitaxel and carboplatin. This study also demonstrated much higher toxicity in the group with intraperitoneal drug administration and only $42 \%$ of patients in the intraperitoneal arm completed their planned six cycles of chemotherapy (16). The intraperitoneal chemotherapy has not been adopted as a standard of care and for now it is only recommended in clinical trials. Dose-dense scheduling to improve the effectiveness of chemotherapy has also been explored in ovarian cancer. A Japanese study (NOVEL-JGOG 3062) compared the standard 3-weekly paclitaxel and carboplatin regimen with the same dose of carboplatin every 3 weeks (AUC 6) and paclitaxel administered in a weekly dose of $80 \mathrm{mg} / \mathrm{m}^{2}$. This trial demonstrated significant benefits in PFS and at 3 years but also increased toxicity. $36 \%$ of patients had to stop this regimen prematurely due to side-effects, especially myelotoxicity (17). The two large clinical trials from Italy (MITO7) and the United States of America (GOG 262) failed to confirm a benefit of weekly paclitaxel $(18,19)$. Dose-dense administration of paclitaxel currently can only be considered an option, and not as a standard of care.

A wide range of targeted agents have being and still are investigated in the treatment of ovarian cancer. Clinically, the most commonly used drugs currently are antiangiogenic drugs and poly (ADP-ribose) polymerase inhibitors. Bevacizum$\mathrm{ab}$ is the first targeted therapeutic drug approved in the first-line ovarian cancer therapy. It is a monoclonal antibody targeting vascular endothelial growth factor. It is approved due to the results of two randomized controlled Phase III trials: GOG-0218 and ICON-7 study $(9,10)$. The clinical trial phase III GOG-0218 included only patients with stage III-IV and macroscopic residual disease after surgery. This trial was a three-arm placebo-controlled study investigating the addition of bevacizumab $15 \mathrm{mg} / \mathrm{kg}$ to standard carboplatin and paclitaxel chemotherapy and patients were treated either with standard chemotherapy alone, standard chemotherapy with concurrent bevacizumab followed by placebo maintenance, or standard chemotherapy with concurrent and maintenance bevacizumab every 21 days for up to 22 cycles (for up to 15 months).The median PFS was significantly increased in patients receiving prolonged bevacizumab (upfront and as maintenance therapy) when compared with chemotherapy alone. PFS was not significantly increased in patients who did not receive maintenance therapy with bevacizumab. There was no difference in OS (9). An analysis of the data from GOG-0218 trial demonstrated that patients with ascites who received bevacizumab regimen had significantly improved PFS and OS when compared with patients who only received chemotherapy (20). Also, regarding the OS, a better prognosis was shown for patients with FIGO IV stage of disease (21). ICON-7, the clinical trial phase III also investigated adding bevacizumab to the standard chemotherapy. The trail design differs from GOG-0218 trial. This trial included women with newly diagnosed ovarian cancer that was either high-risk early-stage disease (FIGO stage I-IIa, grade 3 or clear cell histology) or more advanced disease (FIGO stage IIb-IV). It was a two-arm placebocontrolled study and it compared standard carboplatin and paclitaxel chemotherapy alone or the same chemotherapy with concurrent bevacizumab at $7.5 \mathrm{mg} / \mathrm{kg}$ every three weeks followed by 12 cycles of maintenance bevacizumab (up to 12 
months). This trial demonstrated a statistically significant improvement in progression-free survival but there was no evident statistically significant impact on overall survival when the entire entered population was considered (10). However, an overall survival benefit was recorded in high-risk patients $(10,22)$. High-risk ovarian patients are patients with FIGO IV stage of disease and with FIGO III stage disease and residual tumor $>1 \mathrm{~cm}$ after surgery. Octavia trial, a singlearm phase II study investigated the efficacy and safety of bevacizumab administrated with firstline dose-dense paclitaxel/carboplatin chemotherapy. Like the ICON-7 trial, this trial also included women with newly diagnosed ovarian cancer that was either high-risk early-stage disease (FIGO stage I-IIA, grade 3 or clear cell histology) or more advanced disease (FIGO stage IIb-IV). The pateints received bevacizumab $7.5 \mathrm{mg} / \mathrm{kg}$ every three week with dose dense chemotherapy (6-8 cyceles), followed by single-agent bevacizumab (up to one year). The median PFS in the entire population was 23.7 months and 18.1 months in the group of high risk population (23). ANTHALIA trial, a phase II study investigated the safety and efficacy of bevacizumab in the neoadjuvant setting. The included patients were randomized (2:1) to receive four cycles of neoadjuvant paclitaxel/carboplatin chemotherapy with or without three concomitant cycles of bevacizumab $15 \mathrm{mg} / \mathrm{kg}$ followed by interval debulking surgery and after surgery the same adjuvant chemotherapy was administrated. Bevacizumab was also reintroduced at cycle 6 and continued for at least 26 cycles. The main aim was to investigate complete resection rate (CRR).The CRR was higher in the group which was received bevacizumab $(58.6 \%)$ versus $51.4 \%$ in group without bevacizumab. When patients who were not operated were excluded, CRR in bevacizumab group was $85.5 \%$. Adverse events $\geq 3$ were similar in both groups (24). These data were confirmed in the MITO16A-Mango OV2A trial (25). The safety and efficacy according to age were investigated by the ROSIA trial, the single-arm study. This trial included women with newly diagnosed ovarian cancer that was either high-risk early-stage disease (FIGO stage I-IIa, grade 3 ) or more advanced disease (FIGO stage IIb-IV). $12 \%$ of the included patients were aged 70 years or older and $4 \%$ were 75 years or older. The included patients received 4-8 cycles of standard or dose-dense chemothera- py with paclitaxel and carboplatin, and bevacizumab 15 or $7.5 \mathrm{mg} / \mathrm{kg}$ every 3 week followed by single-agent bevacizumab until progression or for up to 24 months. Bevacizumab-treated patients aged 70 years or older had higher incidences of anemia, low-grade diarrhea, asthenia, grade $\geq 3$ hypertension and thromboembolic events than those younger than 70 years. Median PFS was similar (23.7 versus 25.6 months) to that in younger patients despite the worse prognosis. Older age should not preclude bevacizumab therapy for ovarian cancer, but elderly patients should be monitored more closely while receiving bevacizumab (26). There are many others ongoing clinical trials that investigate the role of bevacizumab in combination with other targeted drugs in first line therapy setting.

\section{CONCLUSION}

Our results are in concordance with the literature data and show that we can safely add bevacizumab to the first line chemotherapy in patients with advanced epithelial ovarian cancer.

\section{REFERENCES}

1. Bray F, Ferlay J, Soerjomataram I, et al. Global cancer statistics 2018: GLOBOCAN estimates of incidence and mortality worldwide for 36 cancers in 185 countries. CA: A Cancer J Clin. 2018; 68(6):394-424.

2. https://www.hzjz.hr/wp-content/uploads/2017/01/ Bilten-2016_zavrsna.pdf Accessed on: 15th March 2019.

3. Prat J; FIGO Committee on Gynecologic Oncology. FIGO's staging classification for cancer of the ovary, fallopian tube, and peritoneum: abridged republication. J Gynecol Oncol. 2015;26(2):87-89. doi:10.3802/ jgo.2015.26.2.87

4. Colombo N, Sessa C, du Bois A, et al. ESMO-ESGO consensus conference recommendations on ovarian cancer: pathology and molecular biology, early and advanced stages, borderline tumours and recurrent disease. Annals of Oncol. 2019;30:672-705.

5. https://www.nccn.org Accessed on: 15 ${ }^{\text {th }}$ March 2019.

6. Bristow RE, Tomacruz RS, Armstrong DK et al. Survival effect of maximal cytoreductive surgery for advanced ovarian carcinoma during the platinum era: a meta-analysis. J Clin Oncol. 2002;20(5):1248-1259.

7. du Bois A, Reuss A, Pujade-Lauraine E, et al.Role of surgical outcome as prognostic factor in advanced epithelial ovarian cancer: a combined exploratory analysis of 3 prospectively randomized phase 3 multi- 
center trials: by the Arbeitsgemeinschaft Gynaekologische Onkologie Studiengruppe Ovarialkarzinom (AGO-OVAR) and the Groupe d'Investigateurs Nationaux Pour les Etudes des Cancers de l'Ovaire (GINECO). Cancer 2009;115:1234-1244.

8. Makar AP, Tropé CG, Tummers P, Denys H, Vandecasteele K. Advanced Ovarian Cancer: Primary or Interval Debulking? Five Categories of Patients in View of the Results of Randomized Trials and Tumor Biology: Primary Debulking Surgery and Interval Debulking Surgery for Advanced Ovarian Cancer. Oncologist. 2016;21(6):745-754.

9. Burger RA, Brady MF, Bookman MA, et al. Gynecologic Oncology Group Incorporation of bevacizumab in the primary treatment of ovarian cancer. N Engl J Med. 2011; 365(26):2473-2483.

10. Perren TJ, Swart AM, Pfisterer J, et al. A phase 3 trial of bevacizumab in ovarian cancer. N Engl J Med. 2011; 365(26):2484-2496.

11. Vergote I, Tropé CG, Amant F, et al. Neoadjuvant chemotherapy or primary surgery in stage IIIC or IV ovarian cancer. N Engl J Med. 2010;363:943-953.

12. Giede KC, Kieser K, Dodge J, Roden B. Who should operate on patients with ovarian cancer? An evidencebased review. Gynecol Oncol. 2005 Nov;99(2):447-461. doi: 10.1016/j.ygyno.2005.07.008

13. Engelen MJ, Kos HE, Willemse PH, Aalders JG, de Vries EG, Schaapveld M, Otter R, van der Zee AG. Surgery by consultant gynecologic oncologists improves survival in patients with ovarian carcinoma. Cancer. 2006;106:589-598.

14. Harter P, Sehouli J, M.D., Lorusso D, et al. A Randomized Trial of Lymphadenectomy in Patients with Advanced Ovarian Neoplasms. N Engl J Med. 2019; 380:822-832. DOI: 10.1056/NEJMoa1808424

15. Ozols RF,Bundy BN, Greer BE, et al. Phase III trial of carboplatin and paclitaxel compared with cisplatin and paclitaxel in patients with optimally resected stage III ovarian cancer: a Gynecologic Oncology Group study. J Clin Oncol. 2003 Sep 1;21(17):31943200.

16. Armstrong DK, Bundy B, Wenzel L, et al. Intraperitoneal cisplatin and paclitaxel in ovarian cancer. N Engl J Med 2006;354:34-43.

17. Katsumata N, Yasuda M, Takahashi F, et al. Dosedense paclitaxel once a week in combination with carboplatin every 3 weeks for advanced ovarian cancer: a phase 3, open-label, randomised controlled trial. Lancet 2009;374:1331-1338.

18. Pignata S, Scambia G, Katsaros D, et al.Carboplatin plus paclitaxel once a week versus every 3 weeks in patients with advanced ovarian cancer (MITO-7): a randomised, multicentre, open-label, phase 3 trial. Lancet Oncol. 2014 Apr;15(4):396-405.

19. Chan JK, Brady MF, Penson RT, et al. Weekly vs. every-3-week paclitaxel and carboplatin for ovarian cancer. N Engl J Med. 2016;374:738-748.

20. Ferriss JS, Java JJ, Bookman MA, et al. Ascites predicts treatment benefit of bevacizumab in front-line therapy of advanced epithelial ovarian, fallopian tube and peritoneal cancers: an NRG Oncology/GOG study. Gynecol Oncol. 2015;139(1):17-22.

21. Burger RA, Enserro D, Tewari KS, et al. Final overall survival (OS) analysis of an international randomized trial evaluating bevacizumab (BEV) in the primary treatment of advanced ovarian cancer: a NRG oncology/Gynecologic Oncology Group (GOG) study. J Clin Oncol. 2018;36(15 Suppl):5517.

22. Oza AM, Cook AD, Pfisterer J, et al. Standard chemotherapy with or without bevacizumab for women with newly diagnosed ovarian cancer (ICON7): overall survival results of a phase 3 randomised trial. Lancet Oncol. 2015;16:928-936.

23. Gonzalez-Martin A, Gladieff L, Tholander B, et al. OCTAVIA Investigators Efficacy and safety results from OCTAVIA, a single-arm phase II study evaluating front-line bevacizumab, carboplatin and weekly paclitaxel for ovarian cancer. Eur J Cancer. 2013;49(18):38313838.

24. Rouzier R, Gouy S, Selle F, et al. Efficacy and safety of bevacizumab-containing neoadjuvant therapy followed by interval debulking surgery in advanced ovarian cancer: results from the ANTHALYA trial. Eur J Cancer. 2017;70:133-142.

25. Daniele G, Lorusso D, Scambia G, et al. Feasibility and outcome of interval debulking surgery (IDS) after carboplatin-paclitaxel-bevacizumab (CPB): a subgroup analysis of the MITO-16A-MaNGO OV2A phase 4 trial. Gynecol Oncol. 2017;144(2):256-259.

26. Selle F, Colombo N, Korach J, et al. Safety and efficacy of extended bevacizumab therapy in elderly $(\geq 70$ years) versus younger patients treated for newly diagnosed ovarian cancer in the International ROSiA study. Int J Gynecol Cancer. 2018;28(4):729-737.

Corresponding author: Kristina Katić, Department of Gynaecology and Obstetrics, University Hosiptal Centre Zagreb, Petrova 13, 10000 Zagreb, Croatia. e-mail: kristina.katic@kbc-zagreb.hr 